Instructions/Template for Preparing Manuscript for Jendela Nursing Journal

\title{
Nursing Analysis in Disorder Patients with Cardiovascular System Approach The Model of the Roy Adaptation Theory
}

\author{
Mutarobin ${ }^{1}$ \\ ${ }^{1}$ Department of Medical Surgical Nursing, Faculty of Nursing, Health Polytecnic Jakarta I, Indonesia \\ Corresponding author: mutarobin@poltekkesjakartal.ac.id
}

\begin{abstract}
Background: The prevalence of patients with an increase in the cardiovascular system is increasing. Nurses are expected to have a contribution in the handling of patients with cardiovascular disorders by implementing and deepening using the Roy Adaptation Model (MAR). The role as care provider was applied to men who were supported 70 years with CAD 3VD EF 52\% POST-CABG X3 OFF PUMP.
\end{abstract}

Purpose: The purpose of the study was to discuss the problem of nursing care in patients with cardiovascular system disorders.

Methods: This study uses a case study design with nursing care given to one patient with a cardiovascular system, age disagreement and does not specify the sex to be used in a case study. Data analysis techniques by analyzing data from the assessment to evaluation and documentation.

Results: The results of the research obtained by policy and stimulus studies can be applied more optimally in the arrangement of ordinary care rooms where patients are stable and not at high risk of reducing cardiac output. Enforcement of attractive nursing diagnoses on NANDA and SDKI. Roy did not arrange specific interventions for each diagnosis based on Roy's Adaptation Model which explained the coping relationships on the regulator and cognator subsystems. Nursing evaluation is completed based on the adaptation achieved by the patient in the mode of adaptation.

Conclusion: Roy's Adaptation Model Theory can be used in providing nursing care to patients with cardiovascular system disorders using a format adapted to the format in the hospital.

\section{Keywords:}

Roy's Adaptation Model, CAD, CABG

\section{LATAR BELAKANG}

Coronary Artery Disease (CAD) atau Sindrom koroner akut (SKA) merupakan suatu gangguan fungsi jantung yang disebabkan karena otot miokard kekurangan suplai darah akibat adanya penyempitan arteri koroner dan tersumbatnya pembuluh darah jantung (AHA, 2017). Bash (2015) dalam studi Biopsycosocial Spiritual Factors Impacting African American Patient's Cardiac Rehabilitation Refferal and Participation menyatakan bahwa sebagian besar dari pasien CAD memiliki historical assessment obesitas (35\%), gaya hidup (30\%), hipertensi (33\%), sindrom metabolik (35\%), pre diabetes melitus $(38,2 \%)$, diabetes melitus $(8,3 \%)$, dan merokok $(20,5 \%)$ laki-laki dan 
$(15,9 \%)$ wanita berkontribusi pada peningkatan prevalensi Atherosclerotic Cardiovascular Disease (ASCVD). Selain itu, sebagian besar pasien CAD juga memiliki clinical assessment seperti nyeri dada, sesak napas, TD systole $<100-150 \mathrm{mmHg}$, dan dyastole $>90 \mathrm{mmHg}$, denyut nadi dalam rentang 50 - $90 \mathrm{x} /$ menit, saturasi $\mathrm{O} 2<85 \%$, peningkatan HDL dan LDL, peningkatan enzim jantung Troponin I, Troponin $\mathrm{T}$, dan CK-CKMB (Bash, 2015).

Perawat dalam membantu pasien memenuhi kebutuhan dan derajat kesehatan pasien yang paling optimal, dituntut untuk menjalankan perannya tidak hanya sebagai pemberi asuhan keperawatan kepada pasien, tetapi juga harus menjalankan peran-peran lainnya untuk melengkapi peran utamanya sebagai seorang pemberi asuhan keperawatan. Ignatavicius \& Workman (2010) mengemukakan bahwa perawat yang mengkhususkan diri dalam bidang keperawatan medikal bedah memiliki tanggung jawab untuk menjalankan peran sebagai pemberi asuhan, pendidik, advokat, dan pembaharu atau innovator.

Perawat menjalankan peran sebagai pelaksana atau pemberi asuhan keperawatan, perawat juga sekaligus menjalankan peran kepemimpinannya agar dapat mempengaruhi perubahan perilaku pasien, menerima atau memberikan konsultasi tim perawat dan tim kesehatan lain untuk memenuhi kebutuhan pasien. Perawat juga harus mengembangkan dan mengidentifikasi sumber-sumber pembelajaran bagi pasien dan keluarga serta memberikan pendidikan tentang rencana perawatan yang sedang dijalaninya agar pasien dapat kooperatif dan mempertahankan perilaku yang positif dan adaptif dalam mencapai status kesehatan pasien seoptimal mungkin.

Dalam menjalankan peran ini, peneliti diharapakan mampu untuk menerapkan asuhan keperawatan dengan menggunakan pendekatan teori model keperawatan. Teori model keperawatan yang digunakan adalah teori model konseptual adaptasi yang dikembangkan oleh Sister Callista Roy yang diterbitkan pertama kali sejak tahun 1970 dan dikenal dengan Model Adaptasi Roy (RAM). Christensen \& Kenney (2009) mengemukakan bahwa sejak diterbitkannya teori ini, secara kontinyu dilakukan perbaikan dan pengembangan agar dapat diterapkan pada berbagai seting keperawatan. Teori RAM ini diterapkan pada pemberian asuhan keperawatan pasien yang mengalami gangguan sistem kardiovaskular. Sindrom koroner akut diangkat sebagai kasus utama, khsususnya Coronary Artery Disease (CAD) dengan pertimbangan bahwa pendalaman pengetahuan dan pengalaman tentang asuhan keperawatan pada gangguan sistem kardiovaskular ini sangat krusial karena angka prevalensi CAD semakin meningkat dari tahun ke tahun dan menjadi penyebab kematian paling sering pada penderita penyakit jantung.

\section{TUJUAN}

Tujuan dari penelitian adalah untuk mengeksplorasi masalah asuhan keperawatan pada pasien gangguan sistem kardiovaskular.

\section{METODE}

Penelitian ini memakai desain studi kasus dengan pendekatan asuhan keperawatan yaitu penelitian dengan cara mengumpulkan data yang dimulai dari pengkajian, menentukan diagnosis, melakukan perencanaan, melaksanakan tindakan, dan melakukan evaluasi 
yang diberikan pada satu orang pasien dengan gangguan sistem kardiovaskular, tidak membatasi umur dan tidak menentukan jenis kelamin yang akan dijadikan dalam sebuah studi kasus. Tujuan dari penelitian ini adalah untuk mengeksplorasi masalah asuhan keperawatan dimulai dari pengkajian sampai dengan evaluasi kepada pasien gangguan sistem kardiovaskular. Analisa data dilakukan sejak peneliti melakukan asuhan keperawatan yang dilakukan mulai awal pengkajian dan dilakukan pendokumentasian pada setiap hari untuk mengetahui perkembangan dari pasien. Studi kasus ini telah mendapatkan izin dari FIK UI dan Rumah Sakit Jantung dan Pembuluh Darah Harapan Kita Jakarta. Teknik analisis data yang dipakai oleh peneliti adalah dengan cara pengumpulan data dengan menggunakan cara wawancara dan observasi pada pasien.

\section{HASIL}

Seorang laki-laki berusia 70 tahun, status: menikah, pendidikan: SMA, alamat: Jalan Ki Anwar Mangku RT 04/15 LK. Palapa Plaju Palembang, pekerjaan: swasta, agama: islam, No. RM: 2018-43-69-43, tanggal masuk: 05-03-2018, tanggal Pengkajian: 05-032018, diagnosa medis: CAD 3VD dengan EF 52\%, dominan kanan, LM stenosis $60 \%$ di distal, LAD stenosis $75 \%$ di proksimal dan $80 \%$ di mid difusse, LCX stenosis $80 \%$ di distal dan osteal OM1 60\%, RCA CTO di proksimal dan kolateral dari LCX.

Keluhan Utama, pasien mengatakan sedikit takut untuk menjalani operasi. Saat ini pasien direncanakan untuk operasi bedah jantung (CABG). Pasien dengan riwayat nyeri dada berulang yang menjalar ke lengan kiri, sesak tidak ada, pasien mengatakan cepat lelah saat berkativitas, pasien mengeluh nyeri pada luka bekas operasi dengan skala 3-5 (0-10), nyeri terasa pada saat latihan napas dalam dan terutama saat akan batuk.

Riwayat Kesehatan Sekarang, tanggal 5 Maret 2018 Pukul 15.00 WIB pasien masuk Ruang IW Bedah rencana untuk dilakukan CABG. Saat di IW Bedah pasien mengatakan tidak ada keluhan. Pasien mempunyai riwayat DM, hipertensi dan merokok. Tanggal 6 Maret 2018 Pukul 12.16 WIB pasien masuk OK untuk dilakukan CABG, saat pengkajian perioperatif didapatkan data tidak ada sesak napas, nyeri dada, pusing, cyanosis. Serah terima rekam medis ada. Tidak ada alat bantu yang terpasang (pacemaker, IABP). Terdapat belang putih di dekat ketiak sebelah kiri. Data hemodinamik awal TD 90/48 mmHg, HR 55 kali/menit, RR $15 \mathrm{kali} / \mathrm{menit}$, suhu 35, $8^{\circ} \mathrm{C}$ dan saturasi oksigen 100\%. Tanggal 6 Maret Pukul 17.30 WIB pasien masuk ke ICU dengan kesadaran SAS 1, terpasang modus ventilator/terapi oksigen $\mathrm{VC} / 50 \%$, rasio inspirasi ekspirasi (1:2), tekanan inspirasi $35 \mathrm{~cm} \mathrm{H} 2 \mathrm{O}$, PEEP $5 \mathrm{H} 2 \mathrm{O}$, RR $10 \mathrm{kali} / \mathrm{menit}$ TV $500 \mathrm{ml}$, FiO2 40\%, gambaran EKG SR, skala nyeri 3-5 (0-10), terpasang ETT. Jumlah drain intra pleura dan intra pericard dari OK $25 \mathrm{cc}$, jumlah output NGT $50 \mathrm{cc}$. Tanggal 7 Maret Pukul 10.00 WIB pasien dipindahkan ke Ruang IW Bedah dan terjadi aritmia dengan irama AF. Tanggal 9 Maret 2018 pukul 13.30 WIB pasien dipindahkan ke ruang perawatan. Tanggal 10 Maret 2018 pasien dipulangkan untuk menjalani rawat jalan dan program rehabilitasi pasca CABG.

Riwayat Kesehatan Dahulu, riwayat mengalami hipertensi, stroke, asma, dan gastritis disangkal oleh pasien. Pasien memiliki riwayat merokok. Riwayat Kesehatan Keluarga, riwayat keluarga mengalami penyakit jantung disangkal. Dalam keluarga tidak ada yang memiliki riwayat asma, hipertensi, stroke. 
Pengkajian Perilaku dan Stimulus Post Operasi, Mode Adaptasi Fisiologis, Oksigenasi, Pengkajian Perilaku, Subyektif: kesadaran SAS 1. Obyektif: menerima pasien dari OK dengan post OP CAB X3, pasien terintubasi sejak dari OK, TD 118/65 mmHg, HR 119 $\mathrm{kali} /$ menit, RR $16 \mathrm{kali} / \mathrm{menit}$, saturasi oksigen $100 \%$, suara napas ronchi halus pada kedua lapang paru, bentuk dada simetris, retraksi dinding dada tidak ada, taktil fremitus kanan ada dan kiri ada, resonance pada kedua lapang paru, bernapas melalui endotracehal tube (ETT), terpasang modus ventilator/terapi oksigen $\mathrm{VC} / 50 \%$, rasio inspirasi ekspirasi (1:2), tekanan inspirasi $35 \mathrm{cmH} 2 \mathrm{O}$, PEEP $5 \mathrm{H} 2 \mathrm{O}$, RR $10 \mathrm{kali} / \mathrm{menit}$, TV $500 \mathrm{ml}$, FiO2 40\%, gambaran EKG SR, skala nyeri 3-5 (0-10), terpasang ETT. Toraks foto (13/02/2018) dengan hasil expertise CTR 54\%, tidak ada kardiomegali, dengan elongasi aorta. Pemeriksaan AGD (06/03/2018) PH 7,36 (7,35 - 7,4), PaCO2 40,6 mmHg(35-45 mmHg), $\mathrm{PaO} 2194 \mathrm{mmHg} \uparrow(80-100 \mathrm{mmHg}), \mathrm{HCO} 3$ 23,0 mEq/L (22-26 mEq/L), BE -1,6 mEq/L $\downarrow$ (-2 s/d +2 mEq/L), SpO2 99,2\% (95-100\%).

Pengkajian Stimulus, Stimulus fokal: ketidakseimbangan suplai dan kebutuhan oksigen miokard, iskemia miokard. Stimulus kontekstual: adanya oklusi di arteri koroner ditunjukkan hasil angiografi LM stenosis $60 \%$ di distal, LAD stenosis $75 \%$ di proksimal dan $80 \%$ di mid difusse, LCX stenosis $80 \%$ di distal dan osteal OM1 60\%, RCA CTO di proksimal dan kolateral dari LCX. Stimulus residual: pola hidup tidak sehat (merokok), sedentary lifestyle, kurang aktivitas.

Sirkulasi, Pengkajian Perilaku, Subyektif: kesadaran SAS 1, Obyektif: TD 118/65 mmHg, HR 119 kali/menit, irama regular dan lemah, RR 16 kali/menit, saturasi oksigen $100 \%$ dengan ventilasi mekanik, konjungtiva ananemis, sklera anikterik, membran mukosa kering, bibir pucat, sianosis tidak ada, CRT $<2$ detik, tidak ada peninggian JVP $\mathrm{CmH} 20$ (5 $\pm 2 \mathrm{mmH} 2 \mathrm{O}$ ), bunyi jantung $\mathrm{S} 1-\mathrm{S} 2$ normal, pulsasi ekstremitas atas dan bawah kuat, gallop tidak ada, murmur tidak ada, ronchi halus ada, pulsasi arteri radialis, femoralis, dan dorsalis pedis adekuat, edema tidak ada, akral hangat, terpasang arteri line arteri radialis kiri, terpasang CVP di vena subclavia kiri, terpasang site port di vena jugularis interna kanan. Hasil pemeriksaan laboratorium (06/03/2018): Hb 9,2 mg/dL $\downarrow$

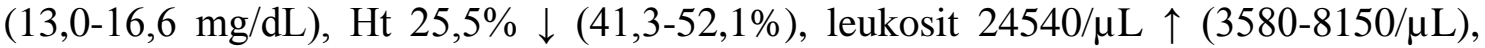
trombosit $125 \mathrm{ribu} / \mu \mathrm{L} \downarrow(172-359 \mathrm{ribu} / \mu \mathrm{L})$. Hasil dari pemeriksaan diagnostik non invasif echo (20/02/2017): ejection fraction EF 52\% (53-70\%) dengan pemberian Dobutamin 20/50 dan Vascon 4/50. Gambaran EKG (06/03/2018): Sinus Rhytm (SR).

Pengkajian Stimulus, Stimulus fokal: ketidakseimbangan suplai dan kebutuhan oksigen miokard, iskemia miokard. Stimulus kontekstual: adanya oklusi di arteri koroner ditunjukkan hasil angiografi LM stenosis $60 \%$ di distal, LAD stenosis $75 \%$ di proksimal dan $80 \%$ di mid difusse, LCX stenosis $80 \%$ di distal dan osteal OM1 60\%, RCA CTO di proksimal dan kolateral dari LCX . Stimulus residual: pola hidup tidak sehat (merokok), sedentary lifestyle, kurang aktivitas.

Nutrisi, Pengkajian Perilaku, Subyektif: pasien mengeluh mual. Obyektif: TB $168 \mathrm{~cm}$, BB $72 \mathrm{Kg}$, IMT $25,5>25 \mathrm{~kg} / \mathrm{cm}^{2}$, status gizi obesitas, diet saat ini $1800 \mathrm{kalori} / 24 \mathrm{jam}$, dengan nilai gizi kalori $1860 \mathrm{kkal}$, protein $62 \mathrm{gr}$, lemak 51,75 gr, karbohidrat 288,3 gr, diet jantung, jenis makanan biasa, abdomen normal, auskultasi bowel sound LUQ, RUQ, RLQ, LLQ normal, perkusi normal, palpasi abdomen keras pada keempat kuadran abdomen, pembesaran abdomen tidak ada, pembesaran splen tidak ada. 
Pemeriksaan laboratorium (06/03/2018): GDS $135 \uparrow \mathrm{mg} / \mathrm{dL}(<100 \mathrm{mg} / \mathrm{dL})$. Pengkajian Stimulus, Stimulus fokal: fungsi insulin tidak efektif. Stimulus kontekstual: pola makan sebelumnya tidak terkontrol. Stimulus residual: riwayat DM sejak tahun 2010 tetapi tidak terkontrol.

Eliminasi, Pengkajian Perilaku, Subyektif: tidak ada keluhan BAK dan BAB. Obyektif: BAK menggunakan DC, intake $1824 \mathrm{cc}$, output 2150, balance cairan -326 cc/24 jam. Frekuensi sebelum sakit 4 kali/hari dengan jumlah $1200 \mathrm{cc}$, warna kuning, tidak ada penggunaan obat diuretik, saat ini pasien tidak mengkonsumsi obat pencahar Laxadine. Pengkajian Stimulus, Stimulus fokal: pasien tidak nyaman BAB di tempat tidur. Stimulus kontekstual: ruangan IW Bedah terbuka sekat antar pasien menggunakan gordyn (privacy kurang menurut pasien). Stimulus Residual: kebiasaan BAB 1 x sehari.

Aktivitas dan Istirahat, Pengkajian Perilaku, Subyektif: pasien mengatakan cepat lelah saat melakukan aktivitas diatas tempat tidur. Obyektif: pasien melakukan ADL dengan total care, cepat lelah saat beraktivitas ada, saat ini pasien bedrest, belum dapat melakukan ROM ekstremitas atas dan bawah, bengkak pada kedua tungkai atas tidak ada, kekuatan otot segmen tangan dan kaki kuat. Pengkajian Stimulus, Stimulus fokal: pasien post tindakan $\mathrm{CABG}$, pasien masih bed rest, dianjurkan untuk tidak banyak berbicara. Stimulus kontekstual: dada pasien terpasaang wire. Stimulus residual: pasien belum pernah mengalami kondisi seperti sekarang ini namun pasien kooperatif terhadap pengobatan dan perawatan yang diberikan.

Proteksi dan Perlindungan, Pengkajian Perilaku. Subyektif: pasien mengatakan nyeri pada daerah operasi. Obyektif: Suhu $37,2^{\circ} \mathrm{C}$, terdapat luka pasca sternotomi, pasien terintubasi dengan ventilator modus ventilator/terapi oksigen $\mathrm{VC} / 50 \%$ r, terdapat akses infeksius vena perifer pada vena dorsomanus kanan, DC ada, terpasang arteri line arteri radialis kiri, terpasang CVP di vena subclavia kiri, terpasang site port di vena jugularis interna kanan, pasien terpasang drain substernal 28 fr dan intrapleura $24 \mathrm{fr}$ kiri. Pengkajian Stimulus, Stimulus fokal: terdapat luka bekas insisi sternotomi mediana dan SVG diambil pada tungkai kaki kanan yang masih tertutup dengan kasa. Stimulus kontekstual: tidak ditemukan perilaku maladaptif. Stimulus residual: peningkatan organisme patogenik dengan hasil pemeriksaan leukosit (06/03/2018) 24540/ $\mu \mathrm{L} \uparrow$ $(3580-8150 / \mu \mathrm{L})$.

Sensasi, Pengkajian Perilaku, Subyektif: pasien mengatakan nyeri pada area bekas operasi. Obyektif: Nyeri dada ada, skala nyeri 3-5 (0-10), ketajaman penglihatan visus mata normal, kojungtiva anemis, sklera anikterik, refleks cahaya $+/+$, tidak ada gangguan penciuman, pengecapan manis ada, asam tidak ada, manis tidak ada, pendengaran $+/+$, tidak ada gangguan pendengaran. Terapi Morphin 10/50 IV. Pengkajian Stimulus, Stimulus fokal: suplai dan kebutuhan oksigen ke miokard belum seimbang. Stimulus kontekstual: pasien post pembedahan OPCABG X3 (LIMA-LAD, SVG-OM, SVG-distal RCA). Stimulus residual: riyawat DM, HT, dan merokok.

Cairan dan Elektrolit, Pengkajian Perilaku, Subyektif: pasien mengatakan sering haus. Obyektif: Iintake 1824 cc, output 2150, balance cairan -326 cc/24 jam, distensi vena jugularis tidak ada, oedema anasarka tidak ada, ascites tidak ada. Pasien terpasang drain substernal $28 \mathrm{fr}$ dan intrapleura $24 \mathrm{fr}$ kiri, produksi drain pada hari 1 post operasi $120 \mathrm{ml}$ 
serosa, hari ke-2 berjumlah $280 \mathrm{ml}$ serosa, hari ke-3 berjumlah $100 \mathrm{ml}$ serosa. Hasil laboratorium $(06 / 03 / 2018)$ : ureum $35,7 \mathrm{mg} / \mathrm{dL}(12,64-42,80 \mathrm{mg} / \mathrm{dL})$, creatinin 1,13 $\mathrm{mg} / \mathrm{dL} \uparrow(0,51-0,95 \mathrm{mg} / \mathrm{dL}), \mathrm{Na} 141 \mathrm{mmol} / \mathrm{mL}(135-153 \mathrm{mmol} / \mathrm{L}), \mathrm{K} 3,9 \mathrm{mmol} / \mathrm{L}(3,5-$ 5,1 mmol/L), Cl $104 \mathrm{mmol} / \mathrm{L}$ (98-109 mmol/L), Ca 1,24 $\downarrow$ (2,20-2,55 mg/dL), Mg 0,52 $\mathrm{mg} / \mathrm{dL} \downarrow(1,6-2,4 \mathrm{mg} / \mathrm{dL}), \mathrm{CK} 224 \mathrm{U} / \mathrm{L} \uparrow(<190 \mathrm{U} / \mathrm{L}), \mathrm{CK}-\mathrm{MB} 38 \mathrm{U} / \mathrm{L} \uparrow(<25 \mathrm{U} / \mathrm{L})$. Terapi Furosemid 2 x $20 \mathrm{mg}$ IV. Pengkajian Stimulus, Stimulus fokal: injuri miokard vetrikel kanan. Stimulus kontekstual: mekanisme kompensasi akibat penurunan curah jantung. Stimulus residual: tidak ditemukan perilaku maladaptif.

Fungsi Neurologi, Pengkajian Perilaku, Subyektif: pasien mengatakan nyeri pada area bekas operasi. Obyektif: kesadaran kompos mentis, status kognitif dan emosi stabil, koordinasi dan kontrol gerakan tubuh baik, fungsi sensorik dan motorik baik, kelumpuhan atau parasilisis tidak ada syaraf sensori nyeri tusuk ada, suhu ada, sentuhan ada, syaraf koordinasi serebral ada, reflek patella dan achiles ada, skala nyeri VAS 3-5 (0-10) di dada. Pengkajian Stimulus, Stimulus fokal: tidak ditemukan perilaku maladaptif. Stimulus kontekstual: tidak ditemukan perilaku maladaptif. Stimulus residual: tidak ditemukan perilaku maladaptif.

Fungsi Endokrin, Pengkajian Perilaku, Subyektif: riwayat mengalami penyakit DM di sangkal pasien. Obyektif: pembesaran kelenjat tyroid tidak ada, tremor tidak ada, trias DM tidak ada, Pemeriksaan laboratorium (06/03/2018): GDS $135 \uparrow \mathrm{mg} / \mathrm{dL}$ $(<100 \mathrm{mg} / \mathrm{dL})$. Terapi Asetosal 1 x $100 \mathrm{mg}$ PO, Metformin 1 x $500 \mathrm{mg}$ PO. Pengkajian Stimulus, Stimulus fokal: peningkatan gula darah sebagai akibat dari ketidakefektifan fungsi insulin. Stimulus Kontekstual: riwayat DM sejak tahun 2010 tidak terkontrol. Stimulus Residual: pola makan yang kurang sehat, tidak melakukan diit DM.

Laporan Intra Operaratif: selasa, 6 Maret 2018, tipe operasi: elektif, operasi kesatu, tindakan pembedahan: CAD 3 VD, EF 52\%, OP CAB X3: LIMA - LAD, SVG-OM, SVG-distal RCA, penemuan: jantung ukuran besar, kontraktilitas cukup, SVG kanan baik, LIMA baik, Stenosis di LAD, LCx, dan RCA, kalsifikasi di RCA, AXC (Aortic Cross-Clamping Time): tidak ada, circulatory arrest time: tidak ada, pace maker wire: tidak ada, tubes: 28 Fr substernal dan 24 intrapleura kiri, total urine output: $250 \mathrm{cc}$, total perdarahan: $700 \mathrm{cc}$, jenis dan jumlah transfusi darah: tidak ada, komplikasi pembedahan: tidak ada, waktu keadaan keluar dari kamar operasi: ABP 100/58 mmHg, HR 72 bpm (SR), CVP $12 \mathrm{mmHg}, \mathrm{SpO} 2100 \%$ support dobutamine $5 \mathrm{mcg} / \mathrm{kg} / \mathrm{menit}$. No. register implant: Aortic On-X $21 \mathrm{~mm}$ SN: 576206, jaringan yang dikirim ke PA: tidak ada. Induksi anastesi berjalan dengan lancar, dipasang monitor AL (arteri line), CVP (Central Venous Presure) dan site port. Preparasi kulit dengan Chlorhexidine 4\% dan $0,5 \%$ dilanjutkan dengan drapping. SVG diambil dari tungkai kanan, kualitas baik. Insisi sternotomi mediana. LIMA diambil pedicled intrapleural, kualitas baik, kemudian Heparin diberikan. Dilakukan anastomosis LIMA ke LAD, distal SVG-RCA distal dan SVG distal RCA dengan bantuan apex sucker dan stabilizer. Kemudian dilakukan anastomosis proksimal SVG sebanyak 2 buah pada aorta ascendens dengan bantuan side bitting clamp, dilanjutkan anastomosis distal SVG-OM. Perdarahan dirawat seksama, Protamin diberikan. Setelah dipasang 1 drain substernal memanjang intrapleura kanan 28 Fr dan intrapleura kiri 24 Fr. Perikardium ditutup sebagian. Sternum ditutup dengan sternal wire, luka operasi ditutup dengan benang absorbable sintetik. Operasi selesai, 
pasien ditransfer ke ICU dengan hemodinamik ABP 100/58 mmHg, HR 72 bpm (SR), CVP 12 mmHg, SpO2 100\% support Dobutamine $5 \mathrm{mcg} / \mathrm{kg} / \mathrm{menit}$.

Mode Adaptasi Konsep Diri, Pengkajian Perilaku, Sensasi tubuh: mengatakan cemas dengan kondisi kesehatannya. Citra tubuh: tidak pernah menyangka bahwa dirinya akan mengalami serangan jantung, karena selama ini dirinya merasa baik-baik saja dan tidak pernah mengalami keluhan. Konsistensi diri: Pasien mengatakan akan tetap berusaha tetap berobat dan akan menjaga kesehatannya. Ideal diri: ingin segera pulih dan tidak mau dirawat lagi. Moral, spiritual, etika diri: beragama islam, patuh melaksanakan ibadah dan sering berdoa untuk kesembuhannya. Pengkajian Stimulus, Stimulus fokal: menderita sakit sakit jantung. Stimulus kontekstual: kurang informasi mengenai penyakit jantung yang dialaminya serta perawatannya.

Mode Adaptasi Fungsi Peran, Pengkajian Perilaku, Sebelum sakit peran sebagai kepala keluarga dapat dijalankan dengan baik. Pasien kurang aktif di masyarakat karena waktunya terbatas. Saat di rumah sakit pasien sangat kooperatif berperan sebagai pasien. Istri selalu menunggu, hubungan dengan keluarga baik. Selama ini pasien dapat beraktivitas dengan baik. Kegiatan sehari-hari sebagai karyawan swasta. Pasien mengatakan "Selama bekerja, saya memang sering merasa stres, apalagi kalau ada pekerjaan yang seharusnya sudah selesai tapi belum juga selesai, terpaksa harus lembur kerja". Pasien juga mengatakan "mungkin saya sudah tidak bisa lagi bekerja seperti dulu, takut aja kena serangan penyakt jantung lagi". Pengkajian Stimulus, Stimulus fokal: ketakutan terhadap nyeri akut. Stimulus kontekstual: merasa tidak berdaya karena tidak mampu beraktivitas seperti dulu. Stimulus residual: tidak ada.

Mode Adaptasi Interdependen, Pengkajian Perilaku, Pasien mengatakan "Kalau saya sakit lagi, saya pasti merepotkan istri dan anak-anak saya, harus bolak-balik rumah sakit. Saya tidak mau mereka seperti itu. Selama dirawat pasien ditunggu oleh istri dan anaknya secara bergantian. Biaya berobat ditanggung oleh BPJS. Pasien juga mengatakan "Orang yang paling dekat dengan saya adalah istri saya yang selalu menemani saya di RS. Pengkajian Stimulus, Stimulus fokal: tidak ada. Stimulus kontekstual: tidak ada. Stimulus residual: tidak ada.

\section{PEMBAHASAN}

Tahap pengkajian, mode adaptasi fisiologis, nyeri akut. Masalah keperawatan nyeri yang dialami Tn. MT terjadi karena agen pencidera fisiologis, rasa nyeri timbul terutama saat menarik napas dan batuk untuk mengeluarkan sputum. Durasi nyeri tidak terlalu lama, tetapi ekspresi wajah pasien yang tampak meringis menandakan bahwa nyeri yang dirasakan masih sangat mengganggu. Rentang nyeri 2-3 dari rentang nyeri 010. Aspek mode fisiologis yang dilakukan seorang perawat terhadap masalah nyeri merupakan kegiatan non farmakologi dan farmakologi, khususnya pada pasien Tn. MT diberikan kompres dingin pada area yang merasa nyeri dengan meletakkan gel pack, selain itu latih pasien untuk relaksasi dengan menarik napas dalam. Namun apabila tindakan tersebut kurang efektif maka perawat dapat melakukan kolaborasi untuk diberikan terapi. Nyeri dada yang dialami oleh Tn. MT disebabkan oleh stimulus fokal ketidakseimbangan suplai dan kebutuhan oksigen miokard akibat oklusi total pada arteri koroner LAD. Oklusi arteri koroner menyebabkan penurunan perfusi vaskuler miokard dimana dalam waktu 10 detik saja, sel-sel miokard dapat mengalami hipoksia dan jika 
terus berlangsung dalam waktu beberapa menit, sel miokard akan kehilangan oksigen dan glukosa yang akan memicu terjadinya metabolisme anaerob. Metabolisme anaerob berlangsung dan terjadi asam akumulasi laktat. Asam laktat mengiritasi serat saraf miokard dan mentransmisikan pesan nyeri ke saraf-saraf miokard dan serabut-serabut saraf toraks posterior bagian atas.

Perangsangan saraf memunculkan sensasi rasa nyeri dada di bagian kiri dan dapat menyebar ke bahu dan lengan kiri. Kondisi iskemik ini dapat pulih kembali jika berlangsung hanya sekitar 20 menit, dengan pemulihan aliran darah, metabolisme anaerobik terhenti dan sel-sel miokard pulih kembali (Lewis et al, 2011; Smith \& Whitwam, 2006). Nyeri dada yang dirasakan oleh Tn. MT berlangsung lebih dari 20 menit, hal ini mengindikasikan tidak adanya proses pemulihan iskemik yang terjadi dalam waktu 20 menit dan mengakibatkan terjadinya nekrosis atau infark pada miokard otot jantung. Tn. MT dibaringkan di tempat tidur dengan posisi semifowler dan dianjurkan untuk tenang, kemudian pasien diberi oksigen dengan nasal kanul sebanyak 3 liter/menit. Pemberian posisi tidur akan berfungsi untuk meminimalkan aktivitas fisik dan metabolisme sehingga menurunkan kebutuhan oksigen untuk meminimalkan risiko cidera dan nekrosis jaringan miokard otot jantung, sedangkan pemberian oksigen bertujuan untuk meningkatkan ketersediaan oksigen dan pemulihan miokard yang mengalami iskemia namun ternyata pemberian oksigen ini sebaiknya disesuaikan dengan saturasi oksigen pasien (Doenges et al, 2010).

Risiko penurunan curah jantung yang dialami oleh Tn. MT diakibatkan ole injuri miokard dan perubahan kontraktilitas miokard. Hal ini ditandai dengan tekanan darah yang cenderung rendah 108/75 mmHg, sesak napas, hasil ekokardiografi EF 52\%, akinetik apikal luas, anterior dan anteroseptal serta hipokinetik di mid septal, EKG acute anterior extensive dan RV infark. Diagnosa ini ditegakkan setelah dilakukan pengkajian lebih lanjut pada mode fisiologis khususnya pada mode oksigenasi. Diagnosa ini ditegakkan pada hari perawatan ke-2 tanggal 6 Maret 2018. Kondisi hemodinamik sesudah infark miokard bervariasi namun curah jantung dapat menurun. Meningkatnya frekuensi jantung biasanya tidak berlangsung terus menerus kecuali jika terjadi depresi miokard yang hebat. Tekanan darah merupakan fungsi interaksi antar depresi miokard dan refleks otonom. Respon otonom terhadap infark miokard tidak selalu merupakan proses bantuan simpatis terhadap sirkulasi yang mengalami gangguan. Perangsangan ganglion parasimpatis dapat mengganggu hemodinamik, menurunkan frekuensi jantung dan tekanan darah, sebaliknya mempengaruhi curah jantung dan perfusi perifer (Price \& Wilson, 2012). Intervensi yang dilakukan pada Tn. MT adalah hemodynamic regulation dan acute cardiac care, yaitu memonitor TTV, mencatat tanda dan gejala dari penurunan $\mathrm{CO}$, memonitor adanya disritmia, memonitor dispnea, fatique, takipnea dan ortopnea, auskultasi bunyi jantung dan paru, melakukan EKG 12 lead, memberikan obat antikoagulan, memberikan inotropik positif, mengelevasikan bagian kepala tempat tidur, memonitor edema perifer, distensi vena jugularis.

Dalam waktu 10-14 hari setelah mengalami infark miokard, jaringan parut yang baru terbentuk masih sangat lemah. Otot jantung sangat rentan terhadap peningkatan tekanan selama jangka waktu ini akibat ketidakstabilan bagian dinding jantung yang mengalami proses penyembuhan. Peningkatan aktivitas dapat dimulai pada kondisi seperti ini. Setelah 6 minggu mengalami infark, jaringan parut telah menggantikan jaringan 
nekrotik. Pada saat tersebut, area yang mengalami injuri bisa dianggap telah pulih. Area jaringan parut biasanya kurang kompatibel dibandingkan dengan jaringan sekitarnya. Kondisi ini dapat menimbulkan disritmia atau gagal jantung (Lewis et al, 2011). Tn. MT baru dapat beradaptasi dengan level kompensatori terhadap penurunan curah jantung pada hari kedua dengan menunjukkan kriteria status hemodinamik stabil: (EF 52\%, CO 3,5 liter/menit, SV $45 \mathrm{ml}$ ), tekanan darah 100/80 $\mathrm{mmHg}$ dan heart rate $74 \mathrm{x} / \mathrm{menit}$, tidak ada disritmia, haluaran urine adekuat $\pm 3 \mathrm{cc} / \mathrm{kg} / \mathrm{jam}$, tidak ada distensi vena jugularis, tidak terdapat edema, tidak ada angina, bunyi napas tambahan ronchi tidak ada. Kemudian pasien pindah ke IW Bedah dengan kondisi curah jantung yang terus membaik hingga pasien pulang.

Intoleransi aktivitas, merupakan diagnosa keperawatan yang menitikberatkan respon tubuh yang tidak mampu bergerak karena tubuh tidak mampu memproduksi energi yang cukup untuk aktivitas sehari-hari (Herdman, 2012). Gangguan kontraktilitas jantung, darah yang dipompa ke seluruh tubuh yang membawa nutrisi dan oksigen persentasenya menurun. Hal ini berdampak pada suplai ke jaringan, sehingga terjadi hambatan pada proses metabolisme untuk menghasilkan energi. Kondisi inilah yang paling sering ditemukan pada pasien gangguan kardiovaskular yang menimbulkan dampak yang beragam dari tiap-tiap pasien, diantaranya yang nantinya membawa perubahan dalam perawatan diri. Pemenuhan kebutuhan perawatan diri tidak hanya dilakukan pada saat pasien dirawat, namun bagaimana pasien ketika melakukan perawatan diri di rumah juga menjadi tanggung jawab yang besar bagi seorang perawat (Dalal, Doherty, \& Taylor 2012).

Panduan SDKI (2016) menyebutkan bahwa tanda dan gejala mayor objektif untuk diagnosa intoleransi aktivitas ini adalah peningkatan frekuensi jantung $>20 \%$ dari kondisi istirahat, sedangkan untuk peningkatan tekanan darah $>20 \%$ merupakan kriteria minor sehingga hal ini sesuai dengan kondisi yang ditemukan di klinis. Manajemen energi merupakan upaya pengaturan energi yang digunakan untuk menangani atau mencegah kelelahan dan mengoptimalkan fungsi (Bulechek, 2013). Tindakan yang dapat dilakukan seperti peningkatan latihan yang bertujuan untuk meningkatkan kebugaran, manajemen nutrisi untuk menyediakan suplai nutrisi yang diperlukan tubuh untuk membentuk energi, terapi oksigen jika pasien memerlukan bantuan suplai, bantuan dalam pemenuhan ADL, dan meningkatkan kualitas serta kuantitas istirahat tidur. Rehabilitasi kardiovaskular merupakan upaya yang dapat dilakukan dalam rangka peningkatan fungsi aktivitas yang paling maksimum pada pasien yang telah mengalami episode gangguan jantung yang terjadi karena adanya ketidakseimbangan antara pemenuhan suplai oksigen ke otot jantung dan kebutuhannya (Bulechek, 2013).

Mode adaptasi konsep diri: cemas. Kecemasan didefinisikan sebagai suatu keresahan, perasaan ketidaknyamanan yang penyebabnya tidak spesifik oleh individu, rasa khawatir yang ditimbulkan oleh antisipasi terhadap yang membahayakan. Cemas yaitu tanda yang memberi peringatan adanya bahaya yang bisa terjadi dan memampukan seseorang untuk melakukan pengukuran dalam mengatasi sesuatu yang mengancam (Herdman, 2012). Tn. MT mengalami kecemasan karena ketakutan akibat perubahan status kesehatan yang dialaminya dan mengatakan merasa khawatir dengan kondisi tidak pasti dari penyakitnya, keluhan nyeri hebat yang dirasakannya adalah keluhan yang pertama kali. Tn. MT tidak pernah menyangka ternyata keluhan sakit dada yang 
dirasakannya itu serangan jantung, karena selama ini merasa dirinya baik-baik saja.

Intervensi yang diberikan untuk mengatasi kecemasan yang dialami Tn. MT adalah dengan memberikan lingkungan yang tenang untuk mengurangi stimulus dari lingkungan. Selain itu, terkadang stimulus tidak berasal dari lingkungan tetapi dari tenaga kesehatan khususnya perawat. Disadari atau tidak, perilaku perawat yang tergesa-gesa dan terburu-buru saat berada di sekitar pasien dipersepsikan pasien sebagai adanya sesuatu yang tidak beres yang sedang terjadi dan sangat sering persepsi ketidakberesan dikaitkan dengan diri pasien dan menimbulkan kecemasan pada pasien. Sehingga perawat perlu untuk selalu menyadari dan mempertahankan perilaku yang tidak tergesa-gesa serta terburu-buru dan melakukan interaksi ke pasien dengan sikap tenang.

Intervensi lain yang dapat dilakukan untuk menurunkan kecemasan Tn. MT adalah dengan memberikan dukungan kepada pasien dan menggunakan mekanisme koping berdoa, membaca Al-Quran dan memperbanyak dzikir. Dari pengamatan perawat, mekanisme koping dengan pendekatan spiritual seperti ini memberikan rasa nyaman, kedekatan terhadap Tuhan dan doa-doa yang disampaikan memberikan harapan-harapan positif dan meningkatkan kepercayaan diri dalam menghadapi masalah serta kepasrahan menjalani penyakit. Hudak \& Gallo (2012) berpendapat bahwa mekanisme koping dengan pendekatan religius-spiritual meningkatkan kesadaran terhadap adanya pengaruh dan kekuatan luar yang lebih besar serta meningkatkan perasaan terhubung dengan sumber kekuatan tersebut sehingga menimbulkan perasaan tenang bagi pasien. Tn. MT dapat beradatapsi secara kompensatori terhadap kecemasan yang dialaminya. Pasien mulai dapat beradaptasi dan menunjukkan pengendalian diri terhadap cemas pada hari kedua. Tn. MT tampak lebih tenang dan dapat berinteraksi atau berkomunikasi dengan perawat tanpa ekspresi cemas dan tegang. Saat pasien di ruang perawatan, sudah terjadi penurunan skor cemas menjadi 2 (VAS 0-10) yang awalnya 3 pada hari 1 pre operasi.

Sejalan dengan hal tersebut Perry dan Potter (2010) menyatakan bahwa ansietas/ cemas meningkatkan persepsi terhadap nyeri dan nyeri bisa menyebabkan seseorang cemas. Seseorang yang mengalami kecemasan akan menunjukan perilaku penurunan produktifi tas, gelisah, insomnia, kesedihan yang mendalam, ketakutan, perasaan ketidakberdayaan, bingung, khawatir, rasa tidak percaya diri. Secara fisiologis juga akan nampak ketegangan di wajah, suara bergetar, peningkatan ketegangan, hal ini akan berdampak kepada penurunan kualitas hidup penderitanya (Sovodka 2010). Penelitian lain yang dilakukan oleh Cully, Phillips, Kunik, Stanley, \& Deswall (2010) tentang predicting kualitas hidup in veterans with heart failure: role of disease severity, depression and comorbid anxiety menunjukkan bahwa depresi berhubungan dengan penurunan skor kualitas hidup pasien. Bahkan lebih dari itu, menurut McGowan (2011) depresi tidak hanya menurunkan kualitas hidup pasien pasien tetapi juga secara signifikan meningkatkan risiko kematian bagi pasien dengan CAD.

Intervensi yang dilakukan untuk mengadaptasikan pasien dengan perubahan penampilan peran yang dialaminya adalah dengan membantu pasien mengidentifikasi berbagai peran dalam hidup dan mengidentifikasi kekurangan peran dan berdiskusi tentang adaptasi peran yang bisa dilakukan. Tn. MT adalah seorang suami dan kepala rumah 
tangga yang harus bekerja untuk membiayai kehidupan sehari-hari keluarganya. Dalam mendiskusikan strategi dan adaptasi peran baru bagi pasien diperlukan keterlibatan keluarga terutama istri dan anak untuk membuat kesepakatan peran baru yang akan dijalani pasien. Tidak jarang memunculkan konflik dalam keluarga karena tidak adanya kesepakatan tentang harapan dan keinginan peran pasien dari awal. Kesepakatan yang dibuat keluarga akan memunculkan pengertian keluarga akan perubahan peran yang dijalani pasien. Selama pasien menjalani fase pemulihan, Pasien dianjurkan untuk sementara waktu untuk beristirahat dan menjalankan perubahan perannya dengan tidak bekerja terlebih dahulu sampai kemudian kondisinya betul-betul pulih dan siap untuk bekerja serta aktif kembali. Tn. MT dapat beradatapsi secara kompensatori terhadap perubahan penampilan peran yang dialaminya. Pada hari rawat ke-2, pasien mengungkapkan rencana-rencana terkait perubahan peran yang dialaminya, seperti akan membatasi pekerjaan sesuai dengan batas kemampuannya dan tidak akan memaksakan diri dalam bekerja.

Mode adaptasi fungsi peran, penampilan peran tidak efektif Tn MT diartikan sebagai pola perilaku dan pengekspresian diri yang tidak sesuai dengan konteks lingkungan dan harapan (Herdman, 2012). Penampilan peran tidak efektif yang dialami oleh Tn. MT disebabkan oleh status kesehatan saat ini yang tidak memungkinkan pasien bekerja seperti dulu. Setiap harinya pasien bekerja sebagai koordinator proyek yang harus bekerja di luar ruangan yang menguras banyak tenaga. Pasien khawatir tidak dapat menjalankan perannya semula karena ketakutan mendapatkan serangan jantung lagi.Terkait perubahan peran yang terjadi pada pasien miokard infark merupakan suatu pengacauan yang menakutkan dan tidak diinginkan yang mengganggu rasa kontrol pasien terhadap kehidupannya. Pasien mengalami suatu "biographical disruption', yaitu suatu perubahan yang tidak terhindarkan dan dipaksakan dalam kehidupannya. Perubahan yang dialami akibat infark miokard membuat pasien tidak dapat bekerja seperti semula. Intervensi yang dilakukan untuk mengadaptasikan pasien dengan perubahan penampilan peran yang dialaminya adalah dengan membantu pasien mengidentifikasi berbagai peran dalam hidup dan mengidentifikasi kekurangan peran dan berdiskusi tentang adaptasi peran yang bisa dilakukan.

Tn. MT adalah seorang suami dan kepala rumah tangga yang harus bekerja untuk membiayai kehidupan sehari-hari keluarganya. Apalagi saat ini anak Tn. MT sedang kuliah dan butuh biaya yang relatif banyak. Dalam mendiskusikan strategi dan adaptasi peran baru bagi pasien diperlukan keterlibatan langsung keluarga terutama dalam hali ini adalah istri dan anak untuk membuat kesepakatan peran baru yang dijalani pasien. Tidak jarang memunculkan konflik dalam keluarga karena tidak adanya kesepakatan tentang harapan dan keinginan peran pasien dari awal. Kesepakatan yang dibuat keluarga memunculkan pengertian keluarga terhadap perubahan peran yang dijalani pasien. Selama pasien menjalani fase pemulihan. Pasien dianjurkan untuk sementara waktu beristirahat dan menjalankan perubahan perannya dengan tidak bekerja dulu sampai kemudian kondisinya betul-betul pulih dan siap untuk bekerja serta aktif kembali. Tn. MT dapat beradaptasi secara kompensatori terhadap perubahan penampilan peran yang dialaminya. Pada hari rawat ke-2, pasien mengungkapkan rencana-rencana terkait perubahan peran yang dialaminya, seperti membatasi pekerjaan sesuai dengan batas kemampuannya dan tidak memaksakan diri dalam bekerja. 
Hasil penelitian sebelumnya yang dilakukan oleh Alligood \& Tomey (2014) menyatakan bahwa gangguan mode fungsi peran yang sering terjadi pada pasien dengan gangguan sistem kardiovaskular adalah perubahan penampilan peran, sehingga diagnosa utama pada pasien gangguan kardiovaskular adalah penampilan peran tidak efektif. Penampilan peran tidak efektif ini paling banyak terjadi karena ketidakberdayaan. Penyakit jantung yang diderita membuat pasien tidak dapat lagi berperan dan berfungsi seperti yang diharapkan baik yang diharapkan oleh pasien sendiri maupun keluarga tempat kerja dan masyarakat tempat tinggal pasien. Perawat harus membantu pasien untuk membuat strategi perubahan yang dapat dijalani pasien sesuai dengan kondisinya, seperti mengurangi intensitas. Dalam kondisi ketidakberdayaan, pasien memerlukan support system yang baik terutama dari keluarga. Sehingga perawat dapat memfasilitasi pasien dan keluarga untuk menyusun rencana asuhan keperawatan secara bersama-sama tentang perubahan dan strategi penampilan peran yang baru bagi pasien.

\section{SIMPULAN}

Teori Model Adaptasi Roy efektif diterapkan dalam asuhan keperawatan pada pasien dengan gangguan sistem kardiovaskular. Teori model ini memungkinkan perawat memberikan asuhan keperawatan dengan lebih komprehensif untuk membantu pasien meningkatkan kemampuan adaptasinya terhadap perubahan lingkungan baik internal maupun eksternal yang mengancam integritas fisik dan psikologis pasien. Rekomendasi: mengembangkan program pelatihan penerapan teori Model Adaptasi Roy dalam memberikan asuhan keperawatan pada pasien dengan gangguan sistem kardiovaskular.

\section{REFERENSI}

American Heart Association (AHA). (2017). Cardiovascular Disease and Diabetes http://www.org/HEARTORG/Conditions/Diabetes/whyDiabetesMatters/Cardiova scular-Disease-Diabetes UCM 313865 Article.jsp.

Bash, E. (2015). Biopsycosocial Spiritual Factors Impacting African American Patient's Cardiac Rehabilitation Refferal and Participation. 1(March), 1-18. https://doi.org/10.1017/CBO9781107415324.

Bulechek. (2013). Nursing Interventions Classification (NIC). Jakarta: EGC.

Christensen, P. J., \& Kenney, J. W. (2009). Proses Keperawatan, Aplikasi Model Konseptual (Terj. dari Nursing Process: Application of Conceptual Models. 4th Ed). Jakarta: Penerbit Buku Kedokteran EGC.

Cully, J.A., Phillips, L.L., Kunik, M.E., Stanley, M.A., \& Deswal, A. (2010). Predicting quality of life in veterans with heart failure: the role of disease severity, depression, and comorbid anxiety. Behavioral medicine, 36, 70-76.

Dalal, H. M., Doherty, P., \& Taylor, R. S. (2012). Cardiac Rehabilitation. American Family Physician, 80(9), 955. http://doi.org/10.1136/bmj.h5000.

Doenges, M E dkk. (2010). Rencana Asuhan Keperawatan: pedoman untuk perencanaan dan pendokumentasian perawatan pasien. Jakarta: EGC.34-39. http://doi.org/10.1016/j.ijcard.2015.08.155.

Herdman, T Heather. 2012. Diagnose Keperawatan: Definisi dan Klasifikasi 2012-2014. Dialihbahasakan oleh Made Sumarwati dan Nike Budhi Subekti. Barrarah Bariid, Monica Ester, dan Wuri Praptiani (ed). Jakarta: EGC.

Hudak \& Gallo, 2012. Keperawatan Kritis: Pendekatan Asuhan Holistic Vol 1. Jakarta: EGC. 
Ignatavicius, D.D. \& Workman, M.L. (2010). Medical Surgical Nursing: Critical Thinking for Collaborative Care. Sixth Edition. Volume 1. USA: Saunders Elsevier.

Lewis, S. L., Heitkemper, M. M., \& Dirksen, S. R., O־Brien, P. G., \& Bucher, L.(2011). Medical surgical nursing: Assesment and management of clinical Problems (Vol. 2, 8th Ed). St. Louis: Mosby Elsevier.

McGowan, D. (2011). The impact of depression on the pathogenesis of heart failure. British Journal of Cardiac Nursing, 6 (1), 19-25

Perry, A. G; Potter , P. A;. (2007). Fundamental of Nursing (6th ed.). Italy: Elsevier Health Science Division.

Price, S. A. \& Wilson, L. M. (2012). Pathophysiology: Clinical concept of desease processes. St. Louis: Elsevier Science

Roy, S. C., \& Andrews, H. (2009). The Roy Adaptation Model. New Jersey: Pearson Education.

SDKI, DPP PPNI. (2016). Standar Diagnosis Keperawatan Indonesia: definisi dan indikator diagnostik (edisi 1): Jakarta: DPP PPNI.

Sovodka, P. (2010). Secret of Hypnotherapy. Jogjakarta: FlashBooks. 